\title{
JESUS CRISTO ENTRE O ANARQUISMO LIBERTÁRIO DE HAN RYNER E O INTEGRALISMO ESPIRITUALIZANTE DE PLÍNIO SALGADO
}

\author{
Maria Bernardete Ramos Flores \\ Universidade Federal de Santa Catarina - UFSC \\ mbernaramos@gmail.com
}

\begin{abstract}
RESUMO: O assunto desse artigo aborda o uso da imagem de Jesus Cristo, em diferentes aspectos. Para o integralista Plínio Salgado, sob o lema "Deus, Pátria, Família", Jesus em seu resplendor divino provê o Homem Integral. Para o anarquista libertário franco-argelino Han Ryner e sua discípula brasileira Maria Lacerda de Moura, Jesus foi um homem que levara uma vida livre e errante, longe de todo vínculo social. Dá-se ênfase sobre ressalvas e/ou adesões à cristologia nietzschiana, extra-moral e avessa a todas as coerções do cristianismo. O debate fica entre a defesa do indivíduo contra o Estado, por um lado, e de outro, a submissão das forças vitais do indivíduo em prol do Estado Integral. A principal fonte trabalhada são ensaios sobre a vida de Jesus.
\end{abstract}

Palavras-chave: Anarquismo, Integralismo, cristianismo, Jesus Cristo, Anticristo.

\section{JESUS CHRIST AMONG HAN RYNER'S LIBERTARIAN ANARCHISM AND PLINIO SALGADO'S SPIRITUALIZING INTEGRALISM}

\begin{abstract}
The subject of this article discusses the use of the image of Jesus Christ in different ways. For the Integralism of Plínio Salgado, under the motto "God, Fatherland, Family", Jesus in his divine brightness provides the Integral Man. To Han Ryner, franco-algerian libertarian anarchist, and his Brazilian disciple Maria Lacerda de Moura, Jesus was a man who had led a free and wandering life, far from any social bond. Emphasis is placed on reservations and/or adhesions to Nietzschean Christology, extra-moral and averse to all coercions of Christianity. The debate is between the defenses of the individual against the State, on the one hand, and on the other, the submission of the vital forces of the individual in favor of the Integral State. The main source worked on are essays on the life of Jesus.
\end{abstract}

KEYWORDS: Anarchism, Integralism, Christianity, Jesus Christ, Antichrist.

Doutora em História, Professora Titular aposentada da UFSC, Pesquisadora 1B do CNPq. Este artigo contou com a colaboração em pesquisa de Daniel Dalla Zen, mestrando em História na Universidade da Fronteira Sul - UFFS. 
Porque o Estado Integral, essencialmente, é para mim o Estado que vem de Cristo, inspira-se em Cristo, age por Cristo e vai para Cristo. Por Cristo me levantei, por Cristo quero um grande Brasil; por Cristo ensino a doutrina da solidariedade humana e da harmonia social; por Cristo luto; por Cristo vos Conduzo; por Cristo batalharei. (Plínio Salgado). ${ }^{1}$

Siento a la vez la política elevada a religión y la religión elevada a política. Siento la agonía del Cristo español, del Cristo agonizante, Y siento la agonía de Europa, de la civilización que llamamos cristiana, de la civilización grecolatina u occidental. Y las dos agonías son una misma. El cristianismo mata a la civilización occidental, a la vez que ésta a aquél. Y así viven, matándose. (Miguel de Unamuno). ${ }^{2}$

Miguel de Unamuno escrevera em 1924 o livro La agonía del cristianismo. Para o intelectual, precursor do existencialismo cristão espanhol e defensor das ideias republicanas, a civilização ocidental encontrava-se em decadência e junto dela, o cristianismo agonizava. Como o escorpião que, quando se vê ameaçado pelo fogo, pica sua própria cabeça com seu próprio ferrão envenenado, assim também "nuestro cristianismo y nuestra civilización, ¿no son un suicidio de este género?” 3

A questão toda para Unamuno estava no paradoxo que encerrava o lema "Dios, Patria y Rei” que os novos governos estavam imprimindo Estados nacionais. Esse Deus não poderia ser o Deus de Cristo, que fugiu para a solidão da montanha quando as turbas quiseram proclamá-lo rei, e que dissera: 'Mi reino no es de este mundo' (Juan, XVIII, 36), e também: 'Dad al César lo que es del César y a Dios lo que es de Dios'.

1 SAlgado, Plínio. O sentido cristão do Integralismo. Publicação avulsa, agosto de 1937. Disponível em: < http://www.integralismo.org.br/?cont=907\&tx=9 > Acesso em: 28 de março de 2013.

2 UNAMUNO, Miguel de. La agonía Del cristianismo. Buenos Aires: Ed. Losada, 1938. p. 131.

3 Ibid., p. 45. 
(Luc., XX, 25). ${ }^{4}$ Como pode, se perguntava Unamuno, o nacionalismo colocar a pátria acima de tudo, em nome do cristianismo? Este cristianismo que serve aos governos não é o verdadeiro cristianismo de Jesus. Este cristianismo acoplado às políticas do Estado está matando a civilização ocidental. Em nome de um "suposto cristianismo social", os governos integralistas não seguiam Jesus de Nazareno que disse: se queres me seguir abandona pai, mãe, irmãos, esposa e filhos. Cristo não tem nada que ver com sociedade e nem com a propriedade privada. "El cristianismo es un valor del espíritu universal que tiene sus raíces en los más íntimo de la individualidad humana". $\mathrm{O}$ cristianismo tem que ser apolítico. "Porque el cristianismo es el individualismo radical". 6

Começamos com esses excertos do filósofo espanhol Miguel de Unamuno para enunciar o tema desse artigo: o cruzamento de dois pensamentos antagônicos e concorrentes no uso que fizeram da história de Jesus: de um lado, o pensamento de um dos maiores anarquistas libertários, o francês Han Ryner (1861-1938), e que teve no Brasil uma discípula, Maria Lacerda de Moura (1887-1945). Na outra ponta, Plínio Salgado (1895-1975), fundador em 1937 da (AIB) Ação Integralista Brasileira, partido de extrema direita, influenciado pelo fascismo italiano, e teve como singularidade o predomínio da espiritualidade em seu programa. ${ }^{7}$

Han Ryner, francês nascido na Argélia, pacifista e anticlerical resoluto, defendeu a objecção de consciência, propondo um individualismo radical, que não se apoie em nenhuma tradição ou vontade exterior. A consciência individual deve ser o único guia de nossas condutas, ética e moral. Segundo Han Ryner havia três tipos de individualistas: o covarde representado por Montaigne; o egoísta na figura de Stendhal e Nietzsche; e o verdadeiro individualista representado por Sócrates, Epicuro, Jesus e Epíteto. Jesus teria sido um dos maiores individualistas porque vivera livre e errante, alheio a todo vínculo social, foi inimigo dos sacerdotes, dos cultos exteriores e, em geral, de todas as organizações, foi perseguido pelo clero e abandonado pelos juízes,

\footnotetext{
Ibid., p.74.

5 UNAMUNO, Miguel de. La agonía Del cristianismo. Buenos Aires: Ed. Losada, 1938. p. 13.

6 Ibid., p.86.

7 Aqui, não vamos nos deter nas análises sobre o anarquismo, enquanto movimento político que se fez presente nas últimas décadas do século XIX e primeiras décadas do XX. A bibliografia é extensa sobre o tema. Houve diversas tendências e experiências anarquistas. De modo geral, eram contra o Estado e a propriedade privada. Igualmente, não trataremos da história do Integralismo brasileiro, já bastante estudado.
} 
morreu crucificado pelos soldados. ${ }^{8}$ No Brasil, Maria Lacerda de Moura, feminista, anarquista, pacifista, anticlerical, antinacionalista, antifascista, foi discípula de Han Ryner. Conhecida nos meios anarquistas libertários, não somente no Brasil, ela pregava a imagem de Jesus como um revolucionário que defendeu o valor do espírito universal, de raiz na interioridade do indivíduo. Se em nome de Cristo, se em nome do cristianismo, as pátrias, a família e a religião perseguem, martirizam, promovem o militarismo e o armamentismo, então "Cristo nunca foi cristão". 9

Para Plínio Salgado, o anticristianismo grassava a cultura, pregando loas ao paganismo. Contudo, nunca houve uma civilização mais humilhada, mais pobre e mais débil do que a que se presencia neste mundo moderno que busca apenas valores materiais ${ }^{10}$. "A tristeza do Mundo paganizado, da civilização deste século é a maior tristeza da história"11. E pedia que se contemplasse o painel As tentações de Santo Antão, de Hieronymus Boch, no Museu das Janelas Verdes, em Lisboa. No centro do quadro, "a solidão de Cristo". Como nos dias de hoje, "Cristo está solitário". "Quatro notas predominantes ferem a atenção do observador diante da estranha pintura: a licenciosidade sexual, a violência homicida, os seres de formas abstrusas e o abandono do Cristo pelos homens. É uma síntese do século XX." ${ }^{12}$ Boch adivinhara, segundo Plínio Salgado, já no século XVI, o que a irracionalidade iria produzir: a animalização do gênero humano. Boch mostrara que a libertação da lascívia e da violência produz monstros bizarros e cruéis, como as personagens que aparecem em A tentação de Santo Antão com fisionomias de cavalos, bois, macacos, crocodilos, gatos, cães, elefantes, serpentes, aves exóticas e insetos, parecidos com o que produzem os artistas contemporâneos. "A tristeza do Mundo paganizado, da civilização deste século é a maior tristeza da história". ${ }^{13}$ Nesse estado de espírito, somente na lição de Cristo, declarava Plínio Salgado, poderemos encontrar a verdadeira linha do Estado, da sociedade, da Família e do Homem, segundo suas finalidades próprias, seus limites

8 RYNER, Han. Manual Filosófico do Individualista. Rio de Janeiro: Achiamé, s.a., p. 22-25.

9 MOURA, Maria Lacerda de. Civilização Tronco de Escravos. Rio de Janeiro: Civilização Brasileira, 1931. p. 127.

10 SALGADO, Plínio. Madrugada do Espírito. Lisboa: Pro Domo, 1946. p. 68.

11 Ibid., p. 48-49.

12 SAlgado, Plínio. Primeiro, Cristo. Conferência publicada em "Novidades", Lisboa, 29 de outubro de 1945. São Paulo: Voz tio Oeste; (Brasília): INL.1979. p. 3.

13 SALGADO, Plínio. Madrugada do Espírito. Lisboa: Pro Domo, 1946. pp. 48-49. 
próprios, sua própria essência ${ }^{14}$. Só o Integralismo, inspirado nos supremos equilíbrios de Cristo e da sua Igreja, provê o Homem Integral. ${ }^{15}$

Nesse artigo, vamos tratar destes dois eixos de pensamento em disputa. Ambos lançam mão do mesmo avatar, representado na "história" de Jesus: de um lado em nome da vida anárquica de Jesus, defendeu-se o crescimento espiritual do indivíduo, levado a cabo pela sua própria consciência, sem interferência externa, sem as travas das instituições: religião, estado, educação, família, juízes. Uma revolução que se daria na vida diária. De outro, apareceram os integralismos e fascismos que pregavam a revolução do Estado, ancorado no lema Deus, Pátria e Família. Na primeira corrente, insere-se o pensamento do anarquista libertário Han Ryner, avesso ao poder do Estado com todas as suas instituições. Na outra corrente, abordaremos o pensamento de Plínio Salgado, o líder do integralismo brasileiro, que lançava mão da imagem de Jesus divino, como vetor para o fortalecimento do Estado, necessário para integrar a sociedade, a família e o homem integral.

\section{JESUS HISTÓRICO}

Desde meados do século XIX, a sensação de uma derrocada da modernidade racional, industrial, utilitarista, materialista, racionalista e imperialista, fazia emergir uma corrente de pensadores que pressentiam o ocaso do Ocidente. As incertezas quanto ao futuro eram cada vez mais difundidas, cuja tese fora apresentada em $O$ declínio do Ocidente de Oswald Spengler, no pós imediato à Primeira Grande Guerra. Afirmava-se que se o cristianismo fora o grande condutor da Civilização Ocidental, era ele agora o causador da derrocada pelos desvios que havia assumido na sua história. Contudo, paradoxalmente, era em nome do cristianismo que se procurava o caminho da regeneração. Não foram poucos os artistas e pensadores que puseram em questão o cristianismo, como causa da tragédia ou como solução para evitar o desastre final. Da denúncia da crise emergiram diferentes crenças, complexas e difíceis de serem traduzidas com clareza: houve os que pregavam a volta aos valores espirituais perdidos, movimento mais místico e espiritual do que institucional; houve os que defendiam a

\footnotetext{
14 Ibid., p. 142.

15 Ibid., p. 110.
} 
"restauração" da igreja do Vaticano, enfraquecida com a laicização da cultura desde a Revolução Francesa; os que pregavam uma reforma católica radical com um retorno ao cristianismo primitivo; muitos engrossavam as fileiras do anticlericalismo.

Foi nesse contexto que apareceu um novo interesse pela figura de Jesus. Diversos exegetas, teólogos, ensaístas, historiadores, pensadores e artistas visuais, tentaram desvendar quem foi Jesus de Nazaré: Tolstoi, Proudhon, Renan, Strauss, Bakunin, González Prada, Plínio Salgado, Han Ryner, entre outros. Jesus de Nazaré foi um homem histórico ou uma divindade? Ou Ele encerra as duas dimensões: humano e divino? Nesse duplo, encerra-se o desejo de que esse Ser venha socorrer a humanidade em estado de agonia diante de um mundo que se desmorona. Como humano é testemunha do sofrimento terreno, como divino porta a esperança de que haja salvação por trás das aparências. Se observarmos o Crucifixion blanche (1938) de Chagall, Jesus apresenta-se com aureola, um atributo da divindade de Jesus. Mas, a imagem contém também traços de humanidade, simbolizada no xale que lembra uma peça de roupa judia, o que reporta à origem judaica do artista, no momento de angústia e denúncia do antissemitismo. O Jesus de Chagal, como figura central desta obra, amparado por um grande raio de luz, por sobre um cenário de guerra, assume a função simbólica do sofrimento que alude a uma ordem eterna divina por trás da miséria humana, uma presença iconográfica do martírio real perene na história da humanidade.

Marc Chagal pintou a crucificação por mais de vinte vezes, mas não foi o único a se dedicar ao tema. Georges Rouault, expressionista, pintou Jesus em diversas expressões, subscritas com versículos bíblicos ou frases que reforçam o pathos do Redentor, vítima da opressão, do sofrimento, da resignação e da esperança. A série Miserere representa a dedicação do artista em plasmar sua crença no poder do sofrimento de Jesus para redenção da humanidade. O cubista místico Albert Gleizes pintou a crucificação de Jesus composto por diversas aureolas sobrepostas, que vão da superfície à profundidade e do visível ao invisível, acreditando que haveria uma unidade cósmica, tal como era expressa na longa história da humanidade, pelos cristãos dos primeiros tempos. O Cristo de Edvard Munch (Gólgota, 1900), na sua magreza e solidão, destaca-se por sobre uma população de aparência ainda mais sofrida, cheia de 
expressões de horror. São muitos os exemplos de artistas modernistas que se dedicaram a retratar Jesus. ${ }^{16}$

Junto com as ciências positivas, aparecia o interesse em discutir sob a ótica da razão a vida do Salvador e se colocava em dúvida ou em tensão a existência puramente divina de Jesus. Vicente Licínio Cardoso (engenheiro e escritor brasileiro, positivista), em Vultos e ideias (1924), narra suas impressões da visita a Oberammergau, cidade da Baviera, famosa pela gigante encenação teatral da morte e ressurreição de Cristo. A peça, encenada pelos habitantes a cada dez anos desde 1634, inaugurada por ocasião de uma epidemia na ocasião da Guerra dos Trinta Anos, transformou-se numa grande rememoração. A cidade é toda colorida com cenas do calvário, "reproduzindo fielmente a imagem falsa do corpo de um crucificado" - diz Licínio Cardoso -, o mesmo erro do Cristo de Velásquez, das pinturas do Renascimento, dos pintores do norte que "Rubens procurou em parte corrigir", dos primitivos italianos ou alemães. ${ }^{17} \mathrm{O}$ erro estava, segundo o autor do ensaio, na representação de um cadáver ereto junto ao madeiro. $\mathrm{O}$ corpo de um crucificado, diz ele, além da cabeça pendente para frente, forçaria o repuxamento dos braços presos apenas pelas mãos e pulsos ao madeiro. O corpo, então, com os pés fixos, iria à frente, formando uma espécie de arco presidido pela força de gravidade. Mas, se interrogados, os artistas anônimos de Oberammergau responderiam que o seu Deus não poderia ter morrido como um simples mortal crucificado.

Em 1850, John Everett Millais, pintou o quadro Cristo na casa de seus pais. O tema da vida de Jesus foi bastante explorado pelos pré-rafaelitas. A obra está Cristo na casa de seus pais está ainda carregada de atributos divinos. Pela porta se pode ver um rebanho de ovelhas, que lembra Jesus, conhecido como o Cordeiro de Deus. O corte da mão de Jesus lembra seu estigma. Entretanto, traz um contexto de vida real de um menino no convívio familiar, na oficina de carpintaria de José. O artista foi muito criticado em sua época por retratar a família de Jesus em seu cotidiano como outra qualquer, o que foi encarado pela teologia conservadora como gesto de blasfêmia. Mas essa tendência de representação de Jesus histórico crescia em meio aos estudos sobre a

16 FLORES, Maria Bernardete Ramos. O corpo das imagens de Jesus no Modernismo. In: Xul Solar e Ismael Nery entre outros místicos modernos. Campinas/SP: Mercado de Letras, 2017. pp. 209-230.

17 CARDOSO, Vicente Licínio. Vultos e Ideias. Rio de Janeiro: Annuario do Brasil,1924. p. 240. 
origem do cristianismo, assumidos tanto pela ciência histórica como pela chamada teologia liberal e, daí, o interesse pela figura de Jesus.

Sob a influência das ciências positivas, no século XIX, não somente a história demonstrou interesse na pesquisa sobre o "fundador" do cristianismo. Um braço da teologia liberal dedicou-se ao tema. O conhecimento não se daria mais pela revelação, mas por aquilo que diriam os textos bíblicos, lidos sob a ótica da ciência. O teólogo alemão Albert Schweitzer, da linha conservadora, defendeu uma tese de doutorado em 1906, analisando o "desproporcional" número de produções que se dedicaram ao tema. Para ele, o intento da teologia liberal de investigar a existência de Jesus do ponto de vista histórico redundou num grande fracasso. "A teologia liberal quis situar Jesus em um plano de racionalidade universal e fez dele um mestre de moral, um filósofo humanista, uma criação da burguesia liberal ocidental, mas esse Jesus não existiu." ${ }^{18} \mathrm{O}$ Jesus histórico e permanente, continua Schweitzer, é absolutamente independente do conhecimento histórico e só poderá ser entendido por meio do contato com Seu espírito que ainda está operando no mundo. À medida que temos o Espírito de Jesus, temos o verdadeiro conhecimento de Jesus. As duas concepções de Vida de Jesus, trazidas pelos teólogos ou pelos historiadores, são cheias de inconsistências. ${ }^{19}$

David Strauss foi um dos alvos da crítica de Schweitzer. Teólogo e exegeta alemão, tido como um clássico representante da teologia liberal, é autor do livro Vida de Jesus, publicado em $1838 .{ }^{20} \mathrm{O}$ objetivo era mostrar os aspectos míticos contidos na história real de Jesus. Ou seja, em sua exegese dos textos bíblicos, lidos numa nova ótica, Strauss faz uma distinção entre o Cristo da fé e o Jesus da história. Ernest Renan também foi alvo da crítica de Schweitzer. Filósofo e historiador, nome de primeira grandeza do racionalismo e do pensamento evolucionista do século XIX, a preocupação de Renan, ao escrever Vida de Jesus, lançado em 1863, era entrar no debate contemporâneo ao lado da corrente de teologia liberal. Na introdução, ele informa que seu livro será uma resposta à outra obra com o mesmo título, Vida de Jesus, de David Strauss. ${ }^{21}$ É preciso se afastar, diz Renan, das formas dogmáticas e se encaminhar à

18 SCHWEITZER, Albert. A busca de Jesus Histórico. São Paulo: Fonte Editorial, 2009. p. 7.

19 Ibid., p. 12.

20 BAtAlioto, Marcelo. A ressurreição de Jesus a partir de Andrés Torres Queiruga. Dissertação (Mestrado Teologia), Pontifícia Universidade Católica do Rio de Janeiro, Rio de Janeiro, 2010. p. 17.

21 RENAN, Ernest. Vida de Jesus. São Paulo: Martin Claret, 2004. p. 27. 
busca de Jesus histórico pela ciência. "Se os teólogos liberais refutam explicações desse gênero é porque eles não querem sujeitar o cristianismo às leis comuns dos homens."22

Como resultado de suas pesquisas, Renan caracterizou Jesus como herói e como gênio. Como herói, Jesus fora um dos grandes homens que mudaram a fisionomia da humanidade, aceitou a morte em nome de um sonho. "O incomparável Herói da Paixão, o fundador dos direitos da consciência livre, o perfeito modelo, que todas as almas amarguradas que sofrem hão de estudar para se fortificarem e consolarem". ${ }^{23}$ Como gênio, Jesus tivera uma capacidade humana extraordinária na concretização de seu ideal. "Jesus é o homem que mais energicamente acreditou na realidade do ideal". ${ }^{24}$ A grandiosidade da obra de Jesus não poderia ser atribuído a um simples sonho obsessivo ou a fantasias triviais, perdidas em vãs divagações. “O reino de Deus, então, é o bem, uma ordem de coisas melhor que a existente, o reino da justiça, que o fiel, segundo sua medida, deve contribuir para fundar...". ${ }^{25}$ Concretamente, o mundo que Jesus aspirou e construiu, podia ser criado na terra.

Minha intenção ao abordar estas interpretações históricas da vida de Jesus foi situar o Anticristo de Nietzsche, "Livro que mexeu com as bases do Ocidente cristão."26 Foi para se contrapor à Renan que Nietzsche escreveu $O$ Anticristo, em 1888, publicado em 1895. ${ }^{27}$ A partir da sua teoria da vontade de poder e do porvir do super-homem, Nietzsche refuta a tese de que Jesus teria sido uma espécie de herói e de gênio. Utilizando-se de um método pouco comum, o intuitivo, Nietzsche quis caracterizar o tipo psicológico de Jesus. Ao estabelecer uma analogia entre Jesus e Míchkin, o personagem do romance $O$ idiota de Dostoievsky, como se este fosse uma espécie de avatar moderno do Nazareno, Nietzsche afirma que ambos apresentariam semelhanças: inocência, beatitude, ausência de ressentimento e até uma certa enfermidade. É perceptível a influência de Dostoievski no pensamento e nas formulações das ideias de

22 Ibid., p. 30.

23 RENAN, Ernest. Vida de Jesus. São Paulo: Martin Claret, 2004. p. 355.

24 Ibid., p. 288.

25 Ibid., p. 288.

26 SOUZA, Mauro A. Introdução. In: NIETZSCHE. O Anticristo. Porto Alegre: L\&PM POCKET, 2011. p. 22.

27 Ernest Renan havia escrito uma obra intitulada $O$ Anticristo (1878), mas não me detive sobre esse trabalho. 
Nietzsche sobre a psicologia de Jesus. Segundo Oswaldo Giacoia Jr, Nietzsche considerava Jesus de Nazaré como "o mais interessante decadente". ${ }^{28}$

Como Miguel de Unamuno e Han Ryner, O Anticristo não foi uma crítica a Jesus Cristo, mas à doutrina cristã, por alienar e servir à dominação. O cristianismo, segundo Nietzsche, teria matado a vontade de vida terrena em prol da vida pós mortem. Isto pode ser visto em uma de suas passagens que diz de Cristo: "Esse "bom mensageiro' morreu tal como viveu; ensinou não para 'redimir os homens', mas para mostrar como se deve viver" 29 Não que Nietzsche, em consonância com a noção de vontade de potência, defendesse que a forma de viver de Jesus fosse o que se deveria seguir, já que ele seria do "tipo decadente". Mas, para Nietzsche, na palavra cristianismo, havia um mal-entendido. No fundo, houve só um cristão, e este morreu na cruz. "O Evangelho morreu na cruz." 30 O mal entendido consiste na fé cristã, tal como se tem apresentado no cristianismo histórico. Desvirtuou-se a Boa Nova de Jesus, considerando-a sob a óptica teológica do pecado, da culpa e do castigo; tomando-o como vítima expiatória de um sacrifício expiatório.

Sua maior intriga era com o apostolo Paulo que havia criado uma doutrina cristã como a única, excluindo outras, tiranizando as massas e formando o rebanho cristão. ${ }^{31} \mathrm{O}$ erro mais grave, segundo Nietzsche, está em a doutrina de Paulo não tocar a realidade; a salvação é prometida somente para o "juízo final" ou no "retorno", transferindo os interesses da vida do presente para o futuro ou para uma vida extraterrena. Para o filósofo, a doutrina de Paulo formou-se contra a ciência e o saber, fundamentada na fé. "Eis a fórmula: creio que a fé salva, logo, é 'verdadeira", ${ }^{32}$ Esse cristianismo teria sido culpado pela queda do império romano, um império com alto grau de organização sob condições difíceis. O cristianismo teria sido um vampiro do império romano. "A vitória de Paulo contra Grécia e contra Roma consuma a

28 GIACOIA Jr., Oswaldo. Notas para uma interpretação da figura histórica de Jesus sob o ponto de vista de 'O Anticristo' de Nietzsche. In: SOUZA NETTO, Francisco (Org.). Jesus: Anúncio e Reflexão. Campinas/SP: Unicamp, 2002. pp. 272-312.

29 NIETZSCHE. O Anticristo. Porto Alegre: L\&PM POCKET, 2011. p.66.

30 Ibid., p. 73.

31 Ibid., p.76.

32 Ibid., p.88. 
ascendência do ponto de vista niilista e reativo como instituidor dos supremos valores culturais do Ocidente." $" 33$

Em conclusão, Nietzsche intitula a igreja cristã, como sendo a maior das corrupções, que inverte valores e vive das calamidades, chegando até mesmo a criar calamidades para se eternizar. "O cristianismo tem necessidade da doença (...) $\mathrm{O}$ homem religioso, tal como quer a igreja, é um típico decadente". ${ }^{34}$ Sua frase "Deus está morto" parecia traduzir $O$ Anticristo, que traz de forma acabada o pensamento nietzschiano sobre o cristianismo, continuador do platonismo, como a religião que "pretendeu dominar homens ferozes; o meio de os conseguir é torná-los doentes - o enfraquecimento é a receita cristã para a domesticação, para a civilização" ${ }^{35} \mathrm{O}$ cristão, para Nietzsche, "é o ódio contra o espírito, contra o orgulho, a coragem, a liberdade, a libertinagem do espírito, o que é cristão é o ódio contra os sentidos, contra a alegria dos sentidos, contra a alegria em geral..."36

As críticas nietzschianas aos fundamentos da verdade, absoluta e universal, imprimiram um pensamento niilista que, por um lado, pode ser considerado como "movimento positivo"; já que agora, não se tem mais garantia de nada, é preciso apelar para a própria responsabilidade e liberdade. Por outro, constituiu-se num "movimento negativo", pela prevalência de traços destruidores, como os do declínio, do ressentimento, da incapacidade de avançar, da paralisia, do vale-tudo, do decadentismo. ${ }^{37}$

\section{O ANTICRISTO}

Como chave para a argumentação que se desenrola aqui nesse artigo - o uso dessa personagem, nomeada ora por Jesus, ora Jesus Cristo ou somente Cristo, ora o Nazareno, pelos anarquistas libertários (Han Ryner e sua discípula brasileira Maria Lacerda de Moura) e pelo integralista Plínio Salgado, do pensamento nietzschiano

33 GIACOIA Jr., Oswaldo. Notas para uma interpretação da figura histórica de Jesus sob o ponto de vista de 'O Anticristo' de Nietzsche. In: SOUZA NETTO, Francisco Benjamin de (Org.). Jesus: Anúncio e Reflexão. Campinas/SP: Unicamp, 2002. pp. 272-312. p. 307.

34 NIETZSCHE. O Anticristo. Porto Alegre: L\&PM POCKET, 2011. p. 89.

35 NIETZSCHE. O Anticristo. Porto Alegre: L\&PM POCKET, 2011. p. 55.

36 Ibid., p. 54-55.

37 PECORATO, Rossano. Niilismo. Rio de Janeiro: Zahar, 2007. 
vamos reter a noção de "vontade de potência" 38 , em sua negatividade. Para Han Ryner a "vontade de potência" resulta em "individualismo egoísta", já que há uma luta de uns sobre outros, em concorrência, para impulsionar o progresso. Para Maria Lacerda, $O$ Anticristo de Nietzsche corrobora com suas próprias ideias: crítica ao poder, aversão às instituições, anticlericalismo, defesa do indivíduo, porém, como defensora do individualismo, Nietzsche prega um individualismo egoísta. "Mesmo o individualismo pode ser a máscara do egoísmo, da sordidez, de baixezas ou até do delírio de poder de um Nietzsche dançarino, 'a última moda da loucura"”. 39 Para Unamuno, o progresso civil, que não pode ser feito em nome de Deus, pode ser feito em nome do super-homem nietzschiano, "pero el Cristiano debe crer que o que hay que hacer nos es sobre-humano, sino hombre inmortal, o sea Cristiano". ${ }^{40}$ E quanto à ideia de que Deus está além do bem e do mal, "!no es eso, no! Más allá, Jenseits, é uma fórmula germânica del progressista Nietzsche." 41

Na leitura de Plínio Salgado, a imagem do super-homem nietzschiano, acima do bem e do mal, é a grande inspiradora da violência, da falta de moral, do direito de pisar sobre a tradição. "E, assim, como o marxismo, o nietzschismo vem agravar os desesperos do mundo e transformar os homens em feras." ${ }^{42}$ Em seu livro a Madrugada do espírito, de 1946, afirma que o que estava matando a civilização era o anticristianismo. A modernidade com suas grandes conquistas materiais acarretava ao homem uma "surda tristeza". O materialismo e o sensualismo, frutos do desenvolvimento técnico e racional, acarretavam à civilização esse estado de agonia que se abatera sobre o século XX. Em tudo ressoava a voz de Freud e a de Nietzsche, afirma Plínio Salgado. O primeiro quis demonstrar que a civilização cristã era uma civilização

38 Na teoria da vontade de potência, em Nietzsche, é possível ver algum vestígio darwinista, ao abrigar a noção de concorrência vital. Embora, essa não se justifica pela necessidade de auto-consevação, mas para a superabundância da vida. "A luta pela existência é apenas uma exceção, uma provisória restrição da vontade de viver: a grande e pequena luta voltam-se, em toda parte, para a preponderância, o crescimento e a expansão, conforme a vontade de potência, que é justamente a vontade de vida". MARTON, Scarlett. Nietzsche. Belo Horizonte: Editora da UFMG, 2000. p.57.

39 MOURA, Maria Lacerda de. Civilização Tronco de Escravos. Rio de Janeiro: Civilização Brasileira, 1931. p. 114.

40 Ibid., p. 93.

41 Ibid., p. 58.

42 SAlgado, Plínio. Primeiro, Cristo. São Paulo: Editora Voz do Oeste, 1979 (1. ed. 1946) 
de recalques. ${ }^{43}$ Freud confundira a alegria com o prazer; com ele, o subconsciente ganhou força em detrimento do consciente, o que gerou um caos, pois a consciência era o que mantinha o equilíbrio e disciplinava o homem. "Hoje, o civilizado já não treme diante dos trovões e dos raios; vai ao delírio sentindo o rumor freudiano do seu subconsciente em tropel...”. ${ }^{44}$ Quanto a Nietzsche, esse pregara a ideia de que o cristianismo era portador de um ethos de tristeza. Mas ora, diz Salgado, a civilização cristã produzira Miguel Ângelo; o anticristianismo apresenta-nos as telas dadaístas, e o expressionismo é só pintura de deformidades e desespero. ${ }^{45}$

A tese de Nietzsche, portanto, está errada, diz Plínio Salgado. Não se pode concordar de que o cristianismo seria a causa da formação de um ethos de tristeza. Não se pode concordar com a imagem do Super-Homem. Seus gritos retumbaram no século; forjou um individualismo novo, baseado no desequilíbrio entre a massa dócil e o homem superior onipotente. E ainda, segundo o integralista brasileiro, a moralidade é uma palavra em vã, para Nietzsche. O Super-Homem nietzschiano está acima do Bem e do Mal. Seus direitos não encontram limites. Tudo é bom para ele, desde que possa expandir-se, realizar-se. "O nietzschismo vem agravar os desesperos do mundo e transformar os homens em feras." 46 Pelo contrário, diz Salgado, na concepção integralista, é o Estado inspirado na luz da sabedoria de Cristo que se reveste da Suprema Autoridade político-administrativa da Nação, controlando e orientando todo o dinamismo vital, subordinando-se, aos imperativos da hierarquia natural das coisas, da harmonia social e do bem comum da Nação. ${ }^{47} \mathrm{~A}$ felicidade dessa forma seria um senso de limites, o que não considerava uma resignação ou fraqueza, mas uma sabedoria que estaria na capacidade de renunciar conseguindo dessa forma a verdadeira independência. Somente através do controle dos desejos impulsivos surgiria o verdadeiro Super-Homem. "A vontade desse não é um cata-vento como a dos superhomens desesperados da grande civilização. Ele é o verdadeiro Super-Homem,

43 SALGADO, Plínio. Madrugada do Espírito. Lisboa: Pro Domo, 1946. p. 43.

44 Ibid., p. 56.

45 Ibid., p. 42.

46 SAlgado, Plínio. Primeiro, Cristo. São Paulo: Editora Voz do Oeste, 1979 (1. ed. 1946)

47 SAlGADO, Plínio. O sentido cristão do Integralismo. Publicação avulsa, agosto de 1937. Disponível em: < http://www.integralismo.org.br/?cont=907\&tx=9 >. Acesso em: 28 de março de 2013. 
vencedor de todas as batalhas. A sua casa é a casa da bondade e da paz, da alegria pura e da felicidade perfeita". ${ }^{48}$

Em 1942 vem à luz Vida de Jesus de Plínio Salgado, grosso volume de 619 páginas. Depois de sua fase positivista, o chefe do integralismo brasileiro converteu-se ao espiritualismo e desembocou num catolicismo dos mais fervorosos. Em Notas, ele registrou que ao se aproximar de Cristo, "repugna-lhe a visão positivista de Cristo exposta por Ernesto Renan.” Depois que lera Vida de Jesus do historiador francês, seu "espírito" fora tomado por um desejo: "o de escrever uma Vida de Jesus, capaz de se contrapor à de Renan. Esta ideia vivera vinte anos no meu espírito, até um dia realizarse". ${ }^{49}$ Em apontamentos iniciais de sua Vida de Jesus, Plínio Salgado esclarece que sua obra é baseada em diálogos extraídos dos textos evangélicos, mas principalmente no esforço para recompor o ambiente humano em torno do mestre, seguindo sua própria experiência de vida. Para Plínio, a ciência não é tudo. A ciência não percebe o que só o sábio pode perceber. O sábio é aquele que superou a própria ciência, “convencendo-se de que há sempre novos planos na natureza, desdobrando-se infinitamente sobre os planos já palmilhados e vencidos pela experiência e pelo cálculo." ${ }^{\text {, }}$

Em resumo, ao contrário de Renan que humanizou Jesus, Plínio defende um Jesus todo espiritual, que se eleva à alturas inacessíveis até mesmo aos grandes espíritos da humanidade; nem Sócrates, nem Platão, em toda a magnanimidade de seu coração. ${ }^{51}$ O cristão, por sua vez, é "rico de espírito" e sabe que a fome e a sede de justiça, a que Jesus se refere, "são as que exprimem a mais alta aspiração da Verdade e da Harmonia. É a ânsia pela reconciliação do Homem com Deus, para que se torne possível a paz na terra." ${ }^{2}$ Plínio acredita que o "Reino dos Céus" é uma república de cidadãos livres. ${ }^{53}$ É verdade que é necessário fazer certos sacrifícios, mas não como os estoicos, que fazem da dor um fim, enquanto que para "Jesus é um meio: o meio de nos oferecermos a Deus.

48 SALGADO, Plínio. Madrugada do Espírito. Lisboa: Pro Domo, 1946. p. 71.

49 SAlGADO, Plínio. Apud. TEJADA, Francisco Elias de. Plínio Salgado na tradição do Brasil. Lisboa: Estampa, 1986. Disponível em: http://www.integralismo.org.br/?cont=912\&ox=10 Acesso em: 04/11/2018.

50 SALGADO, Plínio. Vida de Jesus. São Paulo: Panorama, 1942. p. 54.

51 Ibid., p. 258.

52 Ibid., p. 250.

53 Ibid., p. 243. 
O estoico é um conformista; o cristão é um combatente". ${ }^{54}$ E mais uma vez condena a moderna filosofia. "A acusação dos modernos filósofos paganizantes ao cristianismo, de ser esse a doutrina da tristeza, não difere da argumentação dos alcoólatras quando dizem que fora do vinho não podem compreender a alegria."55 A moderna frase de Zaratustra, de Nietzsche, bradando "se quereis seguir-me, apedrejai-me, é um plagio calcado na atitude ciclópica do Batista, que desce do deserto, carregando às costas o cadáver de uma velha Nação, e diz, referindo-se à Verdade que resplandecerá em Cristo: para que Ele cresça é preciso que eu diminua", ${ }^{56}$

Sob outra feita, se para o Integralismo de Plínio Salgado, sob o lema Deus, Pátria e Família, a Igreja Católica Romana era a grande aliada para se encontrar a verdadeira linha do Estado, da sociedade, da Família e do Homem, "segundo suas finalidades próprias, seus limites próprios, sua própria essência»57, o Anarquismo libertário na linha da Han Ryner pregou o anticlericalismo e via como paradoxo o lema Deus, Pátria, Família. Este Deus não poderia ser o mesmo de Jesus, que teve uma vida livre e errante, alheio a todo o vínculo social, à todas as convenções, leis ou instituições.

No Brasil a anarquista Maria Lacerda de Moura foi uma das vozes mais combatentes contra o integralismo de Plínio Salgado, ao ponto de renegar seu filho Jair. "Pois bem: meu filho adotivo morreu." Ela soubera que seu filho havia entrado nas fileiras dos Camisas Verdes de Plínio Salgado. "Virara soldado da Igreja, do Despotismo, do Terror, da Violência pela Violência. Eu, de há muito, me alistei no exército da Paz (...) Estou ao lado dos oprimidos. Os outros estão se aprestando para defender a Igreja, o Capital e o Estado despótico". 58

Se para Plínio, o materialismo capitalista gerara o individualismo nefasto que arrancava o homem da sua nobre missão: a constituição da família como célula do Estado Integral, para Maria Lacerda, o mundo moderno produzira um rebanho humano, jogado na escravidão, para glória e benefício dos grandes industriais, dos políticos e do

\footnotetext{
54 Ibid., p. 260.

55 Ibid., p. 255.

56 Ibid., p. 266.

57 SALGADO, Plínio. Madrugada do Espírito. Lisboa: Pro Domo, 1946. p. 142.

58 MOURA, Maria Lacerda de. Profissão de fé. A Lanterna, São Paulo, n. 388, p. 3, 09/02/1935.
} 


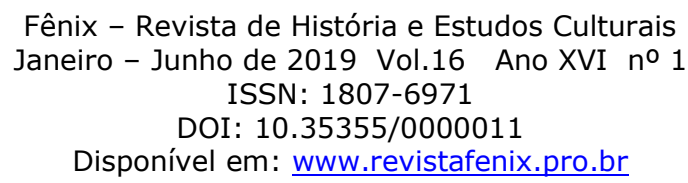

Vaticano, todos cúmplices entre eles. ${ }^{59}$ As pátrias, as bandeiras, a família e a religião perseguem e martirizam, em nome da lei e da moral social, os sonhadores e os poetas do

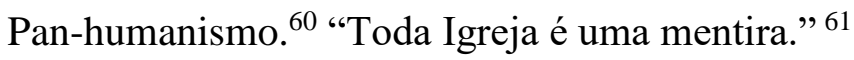

Santa pobreza do Rabi da Galiléa! Santa simplicidade cristã! (...) E, de Cristo, nasceu o cristianismo tartufo. E, de Jesus, fizeram o Jesuitismo da Inquisição e das fogueiras, do confessionário e dos Autos de Fé, de Mussolini e de Tachi Venturi, do óleo de rícino e do manganelo (...) Santa sabedoria cristã (...) E, da humildade mansa do Cristo, nasceu o Vaticano. Como todas as coisas belas se prostituem! Como todos os gestos nobres se vulgarizam em contato com a perversidade humana socialmente, legalmente, moralmente organizada! Santa covardia do rebanho social $6^{62}$

Maria Lacerda chama a atenção para a mudança que houve em Mussolini, que antes citava a celebre frase de Marx: "A religião é o ópio do pobre”. Parecia-lhe incrível que esse mesmo homem, agora "o Dulce da Itália, é o político que fez concordata com a Igreja e entregou a direção espiritual de 42 milhões de italianos ao Vaticano!" Virara um "continuador de Nietzsche", esse Dulce, que considera que as "vantagens excedem os inconvenientes", que se o cristianismo não chegasse em Roma imperial, nunca passaria de uma seita judaica. ${ }^{63}$

Maria Lacerda de Moura é considerada uma das mais destacadas escritoras libertárias no Brasil, defensora da pedagogia libertária e da objeção de consciência, além de feminista no âmbito das questões da sexualidade e da natalidade. Como pensadora, é extensa sua obra publicada em livros e em conferências. Colaborou em diversos jornais anarquistas, no Brasil, Argentina e Espanha. Entre 1928 e 1937, integrou-se à comunidade de Guararema, uma colônia a beira do rio Paraíba, em São Paulo, formada por anarquistas e objetores da consciência, desertores da Primeira Guerra Mundial, italianos, espanhóis e franceses, e que tinham como tema a valorização

59 MOURA, Maria Lacerda de. Civilização Tronco de Escravos. Rio de Janeiro: Civilização Brasileira, 1931. p. 13.

60 Ibid., p. 88.

61 Ibid., p. 112.

62 MOURA, Maria Lacerda de. Civilização Tronco de Escravos. Rio de Janeiro: Civilização Brasileira, 1931. p. 125-127.

63 MOURA, Maria Lacerda de. Fascismo- Filho Dileto da Igreja e do Capital. Campinas: Barricada Libertária, 2012. p. 96. Disponível em: < http://anarkio.net/Pdf/Fascismo_filhodaigreja_capital.pdf > 
da livre associação e do esforço individual. ${ }^{64}$ É de então a colaboração semanal no jornal $O$ Combate de São Paulo, de onde estabeleceu a polêmica de maior repercussão com a imprensa fascista. Nesse período, aprofundou-se na leitura de Sócrates e dos estoicos antigos e passou a ser a divulgadora do pensamento de Han Ryner. Em 1933, publica Han Ryner e o Amor Plural demonstrando que ele foi o seu mestre incondicional. Quando morreu, em 1945, deixou duas obras de Han Ryner traduzidas, sem que fossem publicadas a tempo (Os Pacíficos e O Quinto Evangelho), cujos manuscritos, pelo que consta, não foram mais encontrados. ${ }^{65}$ Para Maria Lacerda, Han Ryner encontrava-se ao lado de Sócrates, Cristo, Epiteto, Epicuro. ${ }^{66}$

Han Ryner foi uma das figuras mais destacadas e reconhecidas no panorama da cultura libertária no primeiro terço do século XX, considerado o grande expoente do pensamento anarquista-individualista ao lado de Max Stirner. Pacifista acima de tudo, valorizou a objecção de consciência e dos meios não violentos de ação. Han Ryner defendeu, especialmente através da literatura que produziu, uma libertação interior e não uma revolução social, coletiva e violenta. Segundo ele, o indivíduo deve agir segundo sua consciência, livre de qualquer condicionamento externo, ouvindo seus próprios impulsos e necessidades e obedecendo apenas quando a preservação de sua individualidade está em jogo.

Em seu Manual Filosófico do Individualista, que na França foi publicado em 1903, apresentou brevemente algumas características de seu pensamento. Segundo Han Ryner havia três tipos de individualistas, como já se disse acima: primeiro o covarde representado por Montaigne (disfarça com máscara filosófica o egoísmo conquistador e agressivo); segundo o egoísta na figura de Stendhal e Nietzsche (estendem às relações dos homens entre si a lei brutal da luta pela vida); e em terceiro o verdadeiro apresentado por Sócrates, Epicuro, Jesus e Epíteto. Han Ryner amava Jesus porque, tendo vivido livre e errante, alheio a todo vínculo social, foi inimigo dos sacerdotes, dos cultos exteriores e, em geral, de todas as organizações. Perseguido pelo clero e abandonado pelos juízes, morreu crucificado pelos soldados. É com Sócrates, a mais

64 LEITE, Miriam Lifchitz Moreira. Maria Lacerda de Moura: uma feminista utópica. Florianópolis: Ed. Mulheres; Santa Cruz do Sul: EDUNISC, 2005. pp. 18-19.

65 RYNER, Han. O Quinto Evangelho. Rio de Janeiro: Germinal, 1961. p. 14-15.

66 MOURA, Maria Lacerda de. O individualismo neo-estoico de Han Ryner (Estudo). Feira Literária. (Publicação mensal laureada pela Academia Brasileira de Letras). São Paulo, 11: 79-80, Nov.1929. 
célebre vítima da religião, o mais ilustre mártir do individualismo. Não se conhece o verdadeiro Jesus porque suas palavras foram desfiguradas pelas organizações e cultos pela mais pomposa e vazia das religiões, o cristianismo. ${ }^{67}$ Contudo, diante do individualismo defendido por Han Ryner, nem Jesus seria "um exemplo" a seguir, pois ninguém deve adotar modelos. Cada qual deve seguir apenas a sua própria consciência. Nem Jesus, nem Sócrates devem ser modelos. ${ }^{68}$ "O meu Deus é proclamado pela minha consciência, a qual constitui a minha voz e não um eco. Os ídolos pelo contrário, são obras da sociedade" ${ }^{69}$

Em 1911, Han Ryner publica O Quinto Evangelho, apresentando um Jesus humano. Um Jesus que em sua opinião teria sido um rebelde, um revolucionário, ou seja, um anarquista, que pregava humildemente e estoicamente um evangelho do amor, da fraternidade e da justiça entre os homens. Na introdução da edição brasileira, Roberto das Neves informa que para Miguel de Unamuno o livro O Quinto Evangelho era uma obra prima, uma obra eterna de beleza e de verdade, que nos apresenta com uma fidelidade e uma poesia superiores às dos evangelhos clássicos, o Cristo ideal, cuja imagem todos nos trazemos no coração. ${ }^{70}$

Han Ryner afirma que o homem Jesủ era contra as leis e a tradição, como se vê em suas palavras: "Vós, porém, empunhando com rudes mãos as tábuas da Lei, convertei-las num fardo que esmaga aqueles a quem a vida já esmagou." ${ }^{.71}$ Em outra passagem: "É mau preocupar-se com as tradições dos antigos e com a Lei. Pois assim se esquece de perguntar-se ao coração o que se deve fazer; e se obedece a escrituras e tradições que, por si, podem ser boas ou más; mas que são sempre, como já vos disse, más, porque fazem olvidar o caminho que conduz às fontes da Verdade e da Vida!". ${ }^{72}$

Em conclusão, conforme a concepção de Han Ryner, o Reino de Deus estaria dentro do coração de cada um, cabendo assim ao indivíduo encontrá-lo em si mesmo. Isto é respondido por Jesus a um fariseu que lhe perguntara quando adviria o Reino de Deus. Em outras palavras Jesus diz "O reino de Deus não virá precedido de anúncios.

67 RYNER, Han. Manual Filosófico do individualista. Rio de Janeiro: Achiamé, s.a. p. 21-25.

68 Ibid., p.38.

69 Ibid., p. 67.

70 RYNER, Han. O Quinto Evangelho. Rio de Janeiro: Germinal, 1961. p. 16.

71 Ibid., p. 81.

72 Ibid., p. 128. 
Ninguém dirá: - Ei-lo aqui ou ei-lo ali. Pois o Reino de Deus não está fora do homem, mas sim dentro do homem, e ninguém pode achá-lo senão em si mesmo". ${ }^{73}$

\section{EPÍLOGO}

Muitos foram os usos políticos da imagem de Jesus nos contextos dos vários movimentos que vão da segunda metade do século XIX à Segunda Guerra Mundial. Nacionalismos, imperialismos, racismos, fascismos, liberalismos e anarquismos, dotaram a figura de Jesus, ora divino, ora humano, ora humano e divino, com roupagens iconográficas e discursivas para seus fins ideológicos e programáticos específicos.

Ser anarquista não significava ser ateu, mesmo que muitos o fossem. Nos jornais anarquistas brasileiros, A Plebe, Spártacus, A Obra, há diversas referências à Jesus. Dois livros de anarquistas foram noticiados em suas páginas. Na edição de $A$ Obra, de 14 jul.1920, n.9, p. 9, noticiou-se a publicação de "um interessante opúsculo Jesus Cristo era Anarquista, de nosso camarada Everardo Dias", cuja edição estava sendo preparada pelo grupo A Plebe. (Não consegui acesso a esse opúsculo). Em $A$ Plebe, 30 mar.1935, n. 85, p. 2, deu-se notícia sobre Cristo, o maior dos anarquistas, de Anibal Vaz de Melo. Este sim, consegui adquiri-lo. Consta no prefácio que o livro fora proibido no Brasil, pelo governo de Getúlio Vargas e, portanto, teve sua primeira edição lançada na Argentina, em 1936. No Brasil, o livro saiu em 1950. Nas páginas introdutórias há vários depoimentos de leitores, com críticas elogiosas, recebidos por ocasião do lançamento na Argentina. "O pensamento de Aníbal Vaz de Melo tem a magia nietzschiana" - escreveu monteiro Lobato. ${ }^{74}$ "O senhor fixou o homem e pelo homem a tarefa de cada um dos grandes guias de nosso tempo, fazendo Cristo o magno centro da História humana" - disse Pietro Ubaldi, da Itália. ${ }^{75}$ Aníbal Vaz de Melo argumenta nessa obra a tese de que a figura de Cristo, da qual se apoderaram os governos fascistas que se revelavam como os maiores inimigos da humanidade, fora deformada. Jesus fora um dos grandes revolucionários sociais, dos nobres e desinteressados agitadores, dos inimigos de todos os políticos, dos que lutam pela causa do povo. Jesus aparece como humano, desertor social, anarco-individualista estoico,

\footnotetext{
73 Ibid., p. 154.

74 MELO, Aníbal Vaz de. Cristo, o maior dos anarquistas. São Paulo: 1950. p. 12.

75 Ibid., p. 19.
} 


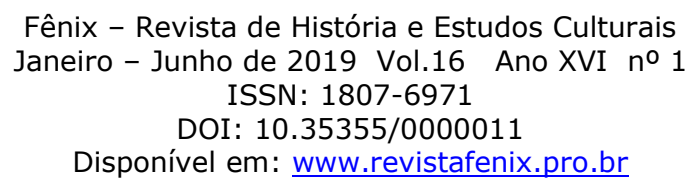

solidário incondicional dos párias e escorraçados da vida, contra o espírito nacionalista, às leis escritas e os tribunais, aos usos e costumes tradicionais, contra o casamento e a família de sangue, amou as meretrizes e defendeu o amor livre.

Nem todo anarquismo foi cristão e nem todo anarquista libertário lançou mão da figura de Jesus ou da espiritualidade para fundamentar a rejeição ao Estado, a propriedade e todas as instituições burguesas. São diversas as fontes do pensamento libertário. Os grandes expoentes são Max Stirner e Fourier, mas individualistas libertários citaram com frequência Dostoievski, Nietzsche, Tolstói, entre outros. Han Ryner cita Jesus e Buda, Francisco de Assis e Francisco Ferrer, Bakunin e Durruti, Kropotkim e Zamennhof, Réclus e Gandhi.

Sobre Nietzsche, nem todos os anarquistas fizeram ressalvas quanto à sua tese da vontade de potência. Os jornais anarquistas brasileiros reverberam em citações de Nietzsche para lhe prestarem deferências. Arsênio Palácios em matéria sobre a necessidade de reforma, publicada em A Plebe, de 21 de mai. 1921, n.118, p.1, abre, com a seguinte citação: "Caminhai direitos a tempos, meus irmãos! Aprendei a caminhar direitos! (...) Eia! Avante! Velhos corações de marinheiros. (Nietzsche)”. Em A Obra, 1 set. 1990, n.12, p. 2, na matéria intitulada A justiça como princípio na sociedade futura, encontra-se a frase: "A civilização helênica e outras também notáveis na antiguidade não foram baseadas na piedade, princípio que pode ser combatido, como foi em nossos dias pelo gênio criador e luminoso de Nietzsche." E numa das estrofes do Hino Libertário, de autoria de Ostavio Brandão, em A Obra, 14 jul. 1920, n.9, p. 10, lêse:

Laus a ti Bakunin alma em peleja. A Kropotkin, a Tucker ou Tolstói E a Nietzsche cujo espírito lampeja E cuja grande dor tanto nos dói $!^{76}$

76 No Brasil, a recepção das obras de Nietzsche vem sendo estudada só recentemente. Conforme Scarlett Marton, houve três ocasiões em que a presença do filósofo alemão entre nós se fez sentir com mais ênfase. No início do século XX, num viés anarquista; depois, seguindo a tendência da época, Nietzsche passou a ser tomado como um pensador de direita apropriado pelo Nazismo alemão; por fim, pós 1968, seguiu-se a leitura da esquerda francesa que privilegia a vertente corrosiva do seu pensamento. Cf. MARTON, Scarlett. Extravagâncias. Ensaios sobre a filosofia de Nietzsche. São Paulo: Discurso Editorial; Editora UNIJUÍ. 2000. p. 204. 
Quanto ao integralismo de Plínio Salgado, o espírito cristão predominou em seu discurso. Exilado em Portugal entre 1939 e 1945, onde terminou de escrever Vida de Jesus, em 1940, em pleno "clima de Festejos, das Comemorações Centenárias", no seio do fascismo salazarista, Plínio era convidado a proferir conferências e palestras a pedido de associações e entidades católicas, sempre com a postura de um "apóstolo de Cristo". Os temas variavam de conferência a conferência, mas o pensamento central era sempre o mesmo, isto é, "aquele que expedi na Vida de Jesus, cujas centenas de páginas podemos sintetizar dizendo que Cristo é o único solucionador de todos os problemas humanos". 77

Essa ênfase na espiritualidade pode se constituir na originalidade do integralismo brasileiro, pondera Gilberto Vasconcellos. "Diferentemente do fascismo italiano e do nacional socialismo, Integralismo um espírito cristão triunfou completamente sobre qualquer base de paganismo." 78 Mas isso não quer dizer, continua Vasconcellos, que a base cristão ou espiritual seja nossa originalidade, lembrando que também a milícia fascista deveria, segundo Mussolini, estar a serviço de Deus e da Pátria. A Igreja, de resto, compactuou com Mussolini, apesar de alguns intelectuais fascistas (Pirandelo, Marinetti e D’Annunzio) terem sido reticentes em relação ao mercantilismo do Vaticano. ${ }^{79}$

A submissão do corpo aos desígnios da alma ou do espírito, do programa integralista, e como ideologia que fortaleceu o capitalismo, deixa clara a ideia de que, sem a repressão dos instintos, a ordem não se estabeleceria. A confusão que gera na nossa compreensão, o fato de o Integralismo condenar o Comunismo, e também o Liberalismo, vai se esvanecendo quando se percebe que depois da crise do Liberalismo do século XIX que desembocara nas crises nas primeiras décadas do século XX Primeira Guerra Mundial, crise econômica de 1929 - a nova fase do capitalismo exigia o controle das sensualidades, da alegria e do prazer, que escapavam à lógica do domínio da razão, com a descoberta do inconsciente freudiano, e com a valorização das forças vitais anunciadas na teoria da vontade de potência nietzschiana. Ambos - Freud e

77 SALGADO, Plínio. A mulher no século XX. São Paulo: Guanumby, 1949. p. 8.

78 VASCONCELloS, Gilberto. A Ideologia Curupira. São Paulo: Brasiliense, 1979. p. 48.

79 VASCONCELlOS, Gilberto. A Ideologia Curupira. São Paulo: Brasiliense, 1979. p. 49. 
Nietzsche - criticados por Plínio, como vimos acima, fragilizaram a força da Suprema Autoridade político-administrativa da Nação.

Daí a agonia que sentia Miguel de Unamuno, ao ver seu Deus conclamado pelos governos repressores. Repetimos a citação com a qual abrimos o artigo: "Como o escorpião que, quando se vê ameaçado pelo fogo, pica sua própria cabeça com seu próprio ferrão envenenado, assim também "nuestro cristianismo y nuestra civilización, ¿no son un suicidio de este género?” ${ }^{80}$ Para Unamuno, quanto mais o cristianismo se enfraquecia, mais apoiava os governos, e menos satisfazia a alma existencialista do poeta filósofo do Existencialismo cristão. Daí a insistência do anarquista liberal individualista Han Ryner em renegar a todos os ídolos e conclamar que obedeçamos apenas à nossa consciência. Os ídolos são perigosos sempre perigosos. Por mais que se ame a Jesus, não se deve transformá-lo em ídolo. Os ídolos estão sempre a exigir sacrifícios da nossa razão e da nossa vontade. No século XX, os principais ídolos, segundo Ryner, estão a exigir o sacrifício da vontade do povo, em nome da "Ordem, do Partido Político, da Religião, da Pátria, da Raça, da Cor”. A Cor Branca é um ídolo perigoso, declara Han Ryner. Costuma unir no mesmo culto franceses, alemães, italianos e russos para linchar os negros e destruir os índios da América. ${ }^{81}$ 
Fênix - Revista de História e Estudos Culturais

ISSN: $1807-6971$

DOI: $10.35355 / 0000011$

Disponível em: www.revistafenix.pro.br 